\begin{tabular}{c} 
International Journal of Scientific World, $6(1)(2018) 31-33$ \\
International Journal of Scientific World \\
SPC \\
Website: $\begin{array}{c}\text { www.sciencepubco.com/index. } h \text { h } / I J S W \\
\text { doi: } 10.14419 / i j s w . v 6 i 1.8745 \\
\text { Research paper }\end{array}$ \\
\hline
\end{tabular}

\title{
The study of Eimeria tenella infections in Poultry Birds in Ekiti State
}

\author{
Adewole S.O ${ }^{1}$, Odeyemi D.F ${ }^{2}$, Aleem S. A. ${ }^{1}$, Omoyeni T.E ${ }^{1}$ \\ ${ }^{I}$ Department of Zoology and Environmental Biology, Faculty of Science, Ekiti State University, Ado, Ekiti State \\ ${ }^{2}$ Department of Science Laboratory Technology (Biotechnology option), Faculty of Science, Ekiti State University, Ado, Ekiti State \\ *Corresponding author E-mail: profadewole@gmail.com
}

\begin{abstract}
In developing countries, animal production is being subjected to great pressure to satisfy the demand for animal protein required by the continuous increasing human population and to have surplus for international trade. Coccidiosis is a major health problem of poultries. This aim of this study is to determine the prevalence of caecal coccidiosis infections in poultry birds in Ekiti State. Three poultry sites were randomly selected and studied in Ekiti state. 10,000 birds were examined out of which 1033 birds tested positive to coccidiosis infection. Test tube floatations for faecal content and wet smear preparation for the caecal lining were done to test the presence of Eimeria tenella $(\mathrm{Et})$ based on the dimension of oocyst and respiratory disease respectively. The result showed the highest percentage of Et infection in Yomi poultry farms in Ifaki Ekiti representing 6.8\% while Daac poultry farms had the least percentage of 3\%. The percentage occurrence of respiratory disease is highest in Daac farms with $6 \%$ and a least percentage of 3\% in Christ's power poultry. The result implies that there is a still presence of Et infections in the poultries considered for study in Ekiti, thus the need for biosafety measures, information and protection programs against the disease.
\end{abstract}

Keywords: Coccidiosis; Eimeria tenella (Et); Parasites; Poultry Birds; Prevalence.

\section{Introduction}

In recent times, poultry industry has experienced a significant expansion in Nigeria. The overall national increase in poultry production has probably triggered vigorous research into alternative and cheaper feed resources needed to sustain such growth and the need to continually focus attention on the health of the animals in other to realize full potentials of the industry [1]. Poultry disease remains one of the major threats to boosting poultry production in Nigeria. Parasitic diseases are of particular importance because of their high incidence in poultry occasioned by the tropical environment under which the farmers operate [2]. Coccidiosis is a poultry disease caused by protozoan parasite species of Eimeria. Et belongs to the class Apicomplexa. Coccidiosis is known to have the greatest economic impact on poultry production, especially in the production of broiler chicken, it is the most expensive and common disease of poultry [3].Poultry birds are susceptible to about nine species of coccidian out of which Et is one of the most common. Coccidian is specific to chickens and cannot infect other types of birds or mammals. The parasite multiplies in the intestine and causes tissue damage, low feed intake, dehydration and blood loss.

Epidemiology studies in Nigeria have established the economic importance of coccidiosis as a major parasitic disease of poultry [4]. The disease occurs throughout the year in Nigeria but with a high prevalence rate from May to September [5], [6].Outbreaks of up to $50 \%$ mortality were reported in commercial poultry in Zaria, Nigeria [7], [8]. A study of the efficacy of drugs in the treatment of coccidiosis in chicken in Ekiti state, out of 61,200 birds examined, 4,287 birds were infected with coccidiosis, which amounts to $7 \%$ disease occurrence [9]. Coccidiosis has been known to be common to intensively managed commercial poultry farms. The prevalence of coccidian infection in indigenous and intensively managed exotic chickens in Nigeria showed $33.3 \%$ of all collected samples with the specific prevalence rate of $44.3 \%$ in layers, $37.1 \%$ broilers and $18.6 \%$ in indigenous chickens. Presence of nitric oxide in blood plasma of chicken indicates Et infection in the chicken [10]. Hemorrhage is a major pathological manifestation of Et infection associated with the disruption of the caecal mucous by the developing parasite [10]. Coccidiosis remains one of the major diseases causing major setback in poultry production despite the advances made in prevention and control through Chemotherapy, management and nutrition. .E. tenella and E. necatrix are the most pathogenic species [11]. The incidence of coccidiosis in commercial poultry has increased due to higher stocking densities and intensive husbandry practices [12]. The study, therefore, focuses on the prevalence of Et infections in poultry chicken within Ekiti state, Nigeria.

\section{Methods}

\subsection{Study site}

Ekiti State is bounded between longitude $7^{0} 15^{1} \mathrm{~N}$ and $8^{0} 5^{1} \mathrm{~N}$ and latitude $4^{0} 5^{1} \mathrm{~N}$ and $5^{0} 45^{1} \mathrm{E}$ of the equator, according to the statistical metrological survey.

\subsection{Sample collection}

Faecal samples of poultry chicken were collected from the different sites with the aid of universal bottles of $5 \mathrm{ml}$ content filled with preservative solution of $10 \%$ formol saline in approximate formula 
of sodium chloride $(0.85 \%-900 \mathrm{ml})$ and formaldehyde $100 \mathrm{ml}$. Each sample bottle was labeled (1-200) A, (1-200) B and (1-200) C to make a total of 600samples from the three sample sites All the collected faecal samples were transported to zoology laboratory, Ekiti State University for further investigation. The supernatant solution was discarded left to remain a faecal residue. Small portion of it was taken with the aid of media spatula and carefully placed into a clean plain slide for microscopic examination.

\subsection{Preparation of wet mounts}

Potassium iodine was dissolved in $30 \mathrm{ml}$ distilled water and stored in a brown bottle as an indicator. The indicator was used to stain the residue placed on plain slides, which was placed for investigation under a binocular microscope for observation.

\section{Result and Discussion}

The result of this study as illustrated in table 1 and 2 shows the percentage of infected birds in each poultry farms studied. Table 1 showed that Daac farms in Ado Ekiti has the highest of Et infection representing 6\% while Christ and Yomi farms has the same percentage occurrence of the infection.

Table 1: Prevalence of Infected Birds in Poultry Farms

\begin{tabular}{|c|c|c|c|c|c|}
\hline Name of farms & $\begin{array}{l}\text { Type of } \\
\text { examina- } \\
\text { tion }\end{array}$ & $\begin{array}{l}\text { Number } \\
\text { of birds } \\
\text { exam- } \\
\text { ined }\end{array}$ & $\begin{array}{l}\text { Num- } \\
\text { ber of } \\
\text { birds } \\
\text { infect- } \\
\text { ed }\end{array}$ & Isolate & $\begin{array}{l}\text { Percent- } \\
\text { age of } \\
\text { infected } \\
\text { birds }\end{array}$ \\
\hline $\begin{array}{l}\text { Daac poultry } \\
\text { farm, Ado Ekiti }\end{array}$ & $\begin{array}{l}\text { Faecal } \\
\text { samples }\end{array}$ & 5000 & 300 & $\begin{array}{l}\text { Eime- } \\
\text { ria } \\
\text { oocyst }\end{array}$ & $6 \%$ \\
\hline $\begin{array}{l}\text { Christ's Power } \\
\text { poultry } \\
\text { farm,IworokoE } \\
\text { kiti }\end{array}$ & $\begin{array}{l}\text { Faecal } \\
\text { samples }\end{array}$ & 2000 & 400 & $\begin{array}{l}\text { Eime- } \\
\text { ria } \\
\text { oocyst }\end{array}$ & $2 \%$ \\
\hline $\begin{array}{l}\text { Yomi poultry } \\
\text { farm, IfakiEkiti }\end{array}$ & $\begin{array}{l}\text { Faecal } \\
\text { samples }\end{array}$ & 3000 & 600 & $\begin{array}{l}\text { Eime- } \\
\text { ria } \\
\text { oocyst }\end{array}$ & $2 \%$ \\
\hline
\end{tabular}

Table 2 showed that Yomi farms had the highest percentage occurrence of respiratory disease. The occurrence of the disease during the study indicates the presence of the causative organism for coccidiosis in poultries in Ekiti State [9].Furthermore, this is an indication that the bio safety procedure employed is not adequate hence enhancing the transmission of the disease across poultries. Infection could also be as a result of storage of feed within the bird housing, thus exposing the birds to contaminated feed. Ignorance of the poultry farms also, played a significant role in the transmission of the disease. Vaccination is known to minimize the poultry against the disease, $50 \%$ of the poultry farmers did not vaccinate their poultry stock hence the occurrence of the disease in their farm

Table 2: Percentage Prevalence of Infected Birds in Poultry Farms

\begin{tabular}{|c|c|c|c|c|c|}
\hline Name of farms & $\begin{array}{l}\text { Type of } \\
\text { examina- } \\
\text { tion }\end{array}$ & $\begin{array}{l}\text { Num- } \\
\text { ber of } \\
\text { birds } \\
\text { exam- } \\
\text { ined }\end{array}$ & $\begin{array}{l}\text { Num- } \\
\text { ber of } \\
\text { birds } \\
\text { in- } \\
\text { fected }\end{array}$ & Disease & $\begin{array}{l}\text { Percent- } \\
\text { age of } \\
\text { infected } \\
\text { birds }\end{array}$ \\
\hline $\begin{array}{l}\text { Daac poultry } \\
\text { farm, Ado } \\
\text { Ekiti }\end{array}$ & $\begin{array}{l}\text { Post } \\
\text { mortem }\end{array}$ & 5000 & 15 & $\begin{array}{l}\text { Respira- } \\
\text { tory } \\
\text { disease }\end{array}$ & $0.3 \%$ \\
\hline $\begin{array}{l}\text { Christ's Power } \\
\text { poultry } \\
\text { farm,Iworoko } \\
\text { Ekiti }\end{array}$ & $\begin{array}{l}\text { Post } \\
\text { mortem }\end{array}$ & 2000 & 10 & $\begin{array}{l}\text { Respira- } \\
\text { tory } \\
\text { disease }\end{array}$ & $0.5 \%$ \\
\hline $\begin{array}{l}\text { Yomi poultry } \\
\text { farm, IfakiEki- } \\
\text { ti }\end{array}$ & $\begin{array}{l}\text { Post } \\
\text { mortem }\end{array}$ & 3000 & 8 & $\begin{array}{l}\text { Respira- } \\
\text { tory } \\
\text { disease }\end{array}$ & $2.6 \%$ \\
\hline
\end{tabular}

\section{Conclusion and Recommendation}

The result of this study indicates that coccidiosis is still prevalent in these poultries which could be as a result of the inadequate biosafety procedures hence increasing the chances of transmission of the disease across poultries. It is therefore recommended that much attention be given to the prevention as well as treatment of the disease in poultry birds so as to have increase production of poultry birds and their resources.

\section{References}

[1] T.Barksh Poultry Parasites and Diseases in African Farming and Food processing.Publised by Allien Charles publishing Ltd.London (2009) .13.

[2] H. Seafert. Tropical Animal Health. Klawee Academic Publishers.Boston. (2006).57.

[3] R.Kiani and H.H.Farhang. Development of an Elisa Test for Serological Diagnosis of Coccidial Infection and Studying of Resistance against Coccidiosis Based on Flock History. Asian Journal of Biological Science. 1(2008) 77-83. https://doi.org/10.3923/ajbs.2008.77.83.

[4] H.P Chapman. Evaluation of efficiency of anticoccidial drugs against Eimeria species in the fowl. International Journal of Parasitology 28 (2008) 1141-1144 https://doi.org/10.1016/S00207519(98)00024-1.

[5] E.B Etuk, I.C Okoli, M.U Uko. Prevalence and Management issues associated with Poultry Coccidiosis in Abak Agricultural zone of AkwaIbom state, Nigeria. International Journal of Poultry Science 3(2) (2004):135-139 https://doi.org/10.3923/ijps.2004.135.139.

[6] P.A Abdul. Manual of Important poultry diseases in Nigeria. 2nd Edition,Macchin Multimedia Designnersm, USA. (2007).91.

[7] P.A Abudu. A.M Wakama, N.D.G Ibrahim and A.Sanusi. Clinical and Pathological features associated with EimeriaNecatrixinfection in Six week old pullets in Zaria,Nigeria Vertinary Clinic practice bulletin.(1)(2008)7-13.

[8] I.W Musa, I.D Saidu,J.Jatau, M.O.Adamu, P.A Abdu. Outbreak of coccidiosis in 5-day old commercial broiler breeder flock in Zaria, Nigeria. International Journal of Poultry Science.(9)( 2010)11121115 .

[9] S.O Adewole. The efficacy of drugs in the treatment of Coccidioisis in chicken in selected poultries.Academic Research International.2(1)(2012)20-24

[10] P.C. Allen Production of free radical species during Eimeria maxima infections in chickens. Poultry Science 76 (1997) 814-821. https://doi.org/10.1093/ps/76.6.814

[11] G.Getachew, T.Getachew. andDorchies. Study on poultry coccidiosis in Tiyo district Arsi zone Ethiopia. International Journal of poultry science.7 (3) (2008).251-256.

[12] B.Ruzica, E Neda,S. Cajavec,,V. Bara, G.Tihomira.Immunoprophylaxis of coccidiosis-contribution to reduction of environment burden caused by intense poultry production. Warsaw Poland Journal 2(2005).11. 